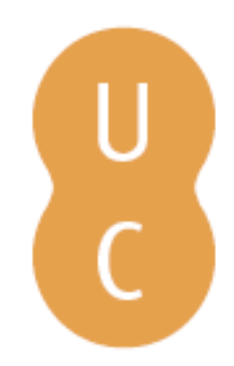

\title{
pombalina
}

\section{Numerical investigations of coupled fire-atmosphere feedbacks influencing fire behavior on slopes}
Autor(es):
Linn, Rodman; Jonko, Alexandra; Winterkamp, Judith; Runde, Isabelle; Sieg, Carolyn; Parsons, Russ; Pimont, Francois

Publicado por: Imprensa da Universidade de Coimbra

URL persistente:

URI:http://hdl.handle.net/10316.2/44678

DOI:

DOI:https://doi.org/10.14195/978-989-26-16-506_161

Accessed : $\quad$ 26-Apr-2023 14:15:05

A navegação consulta e descarregamento dos títulos inseridos nas Bibliotecas Digitais UC Digitalis, UC Pombalina e UC Impactum, pressupõem a aceitação plena e sem reservas dos Termos e Condições de Uso destas Bibliotecas Digitais, disponíveis em https://digitalis.uc.pt/pt-pt/termos.

Conforme exposto nos referidos Termos e Condições de Uso, o descarregamento de títulos de acesso restrito requer uma licença válida de autorização devendo o utilizador aceder ao(s) documento(s) a partir de um endereço de IP da instituição detentora da supramencionada licença.

Ao utilizador é apenas permitido o descarregamento para uso pessoal, pelo que o emprego do(s) título(s) descarregado(s) para outro fim, designadamente comercial, carece de autorização do respetivo autor ou editor da obra.

Na medida em que todas as obras da UC Digitalis se encontram protegidas pelo Código do Direito de Autor e Direitos Conexos e demais legislação aplicável, toda a cópia, parcial ou total, deste documento, nos casos em que é legalmente admitida, deverá conter ou fazer-se acompanhar por este aviso. 


\section{ADVANCES IN}

\section{FOREST FIRE RESEARCH}

\section{8}

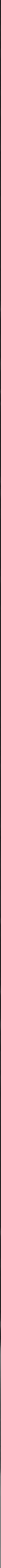


Short contribution - Fire Management

Numerical investigations of coupled fire-atmosphere feedbacks influencing fire behavior on slopes

Rodman Linn $^{1 *}$; Alexandra Jonko ${ }^{1}$; Judith Winterkamp ${ }^{1}$; Isabelle Runde ${ }^{1}$; Carolyn Sieg $^{2}$; Russ

Parsons $^{3}$; Francois Pimont ${ }^{4}$

${ }^{1}$ Los Alamos National Laboratory, Los Alamos, NM, USA.

\{rrl@lanl.gov*,ajonko@lanl.gov, judyw@lanl.gov, isabelle.runde@gmail.com \}

${ }^{2}$ USDA Forest Service, Flagstaff, AZ USA, \{csieg@fs.fed.us \}

${ }^{3}$ USDA Forest Service, Missoula, MT, USA \{rparsons@fs.fed.us \}

${ }^{4}$ URFM INRA. 84914 Avignon, France, \{francois.pimont@inra.fr\}

\begin{abstract}
Numerical simulations with a coupled fire/atmosphere model, FIRETEC, were used to investigate some of the mechanisms through which fire is influenced by topographic slope in the direction of the wind. This investigation focuses its attention on the local two-way feedbacks between the fire and the atmosphere around it. Idealized configurations are used to eliminate some of the complexity associated with variable environmental slope, winds and fuels that are frequently found in real-world wildland-fire situations. The simulated fires burn through homogeneous tall grass with static prescribed upstream wind profiles. Simulations were performed on homogenized slopes in which the upstream wind is aligned parallel to the ground in the direction of maximum slope (wind blowing uphill). Simulations were also performed to investigate the influences of having winds intersect the slope at oblique angles, such as horizontal winds colliding with a slope. The results of these simulations provide insight into some of the phenomenological feedbacks that determine the nature of these macro-scale trends. By changing the local slope, the balances that control the interactions between the fire and surrounding atmosphere, thus changing both the local wind patterns and the fire behavior. Components of the wind perpendicular to the land surface also influence the fire behavior, suggesting the importance of incorporating knowledge of upstream topography into fire behavior predictions. This numerical study takes advantage of the richness of information available in process-based simulations and the control over the environmental conditions that is inherent to this type of tool, but is intended to complement laboratory and field observations, which are not subject to the simplifications or abstractions of fine-scale details in such models.
\end{abstract}

Keywords: wildfire modeling, slope effects

\title{
1. Introduction
}

In order to reliably predict wildland fire behavior, it is valuable to have a fundamental understanding of the environmental factors influencing fires, including topography. Even though numerous observations have noted that fire can be drastically influenced by topography, there are still substantial gaps in our understanding of the phenomenological mechanisms involved. There are many aspects of both local and nonlocal topography that can influence fire behavior, but one of the most commonly recognized topographic factors influencing fire behavior is the local slope of the terrain at the site of the fire. A variety of previous studies have characterized the influences of slope on fire behavior through laboratory (Silvani et al. 2012, Viegas et al. 2013, Liu et al. 2014, Rossa et al. 2015) and field observations (Raposo et al. 2015 ).

Field observations provide critical information regarding the macroscopic behavior in true wildland fire scenarios, potentially including the dynamic evolution of specific state variables at specified locations. However, it is difficult $t$ completely characterize the ambient environment (dynamic winds and fuels), and repeatability is also a significant challenge for field observations. 
Laboratory experiments take advantage of the more tightly controlled conditions and potentially higher-density instrumentation of the laboratory setting. Unfortunately, studying the effects of slope in the presence of an ambient wind is non-trivial in traditional wind tunnels. Identifying cause and effect relationships associated with slope solely through such observations is challenging due to the complex interplay between coexisting local and nonlocal (surrounding) conditions. Process-based coupled fire/atmosphere models can be used to complement such observationally-based investigation, leveraging their repeatability, information richness and opportunity to tailor fire scenarios to investigate specific aspects of fire behavior (Linn et al. 2010, Pimont et al. 2012).

\section{Methods}

A coupled fire/atmosphere process-based wildfire model, FIRETEC, was used to investigate the cause-and-effect process interactions that result in a wildland fire's response to changes in topographic slope. The goal was to use the flexibility of numerical modeling to help isolate the effects of local slope from the those of numerous other topographic factors that can confound the clear observation of slope influences on fire behavior in the field or laboratory. Such other factors include upwind or downwind (or upslope and downslope) topographic features, topographic curvature, topographic gradients aligned with the winds, transient winds, or heterogeneous fuel loading. With this approach we were able to explore idealized combinations of wind and slope that are difficult to study in the field or wind tunnel. We use idealized configurations to eliminate some of the complexity associated with variable environmental slope, winds and fuels that are frequently found in real-world wildland-fire situations. The simulated fires burn through homogeneous tall grass with static prescribed upstream wind profiles. Simulations were performed on homogenized slopes in which the upstream wind is aligned parallel to the ground in the direction of maximum slope (wind blowing uphill) and then influences of having winds intersect the slope at oblique angles we explored, such as horizontal winds colliding with a slope.

\section{Results}

Many of the macro-scale scale trends in fire behavior of this study are consistent with trends that have been observed in previous field, laboratory and numerical investigations, including the steeper slopes causing faster spread rates and more pointed fireline shapes (figure 1). However, the nature of this exploration also provided insight into some of the phenomenological feedbacks that determine the nature of these macro-scale trends. By changing the local slope, the balances that control the interactions between the fire and surrounding atmosphere. The tower and trough fireline dynamics that exists in wind driven fires on flat ground changes as the fireline and wind direction become more aligned and the entrainment patterns near the heading and flanking portions of the fire change. As the depth of the fireline increases with the slope the penetration of the winds through the fireline is hindered, thus increasing the role of winds that are drawn towards the fire from outside the fire perimeter. Slope effects on fire behavior can also be influenced by the alignment of the ambient winds with the hillside, indicating that in nonlocal topographic effects and the position on a hillside (e.g. top of a hill or bottom of a hill) should also be considered in prediction of fire behavior in complex terrain. 

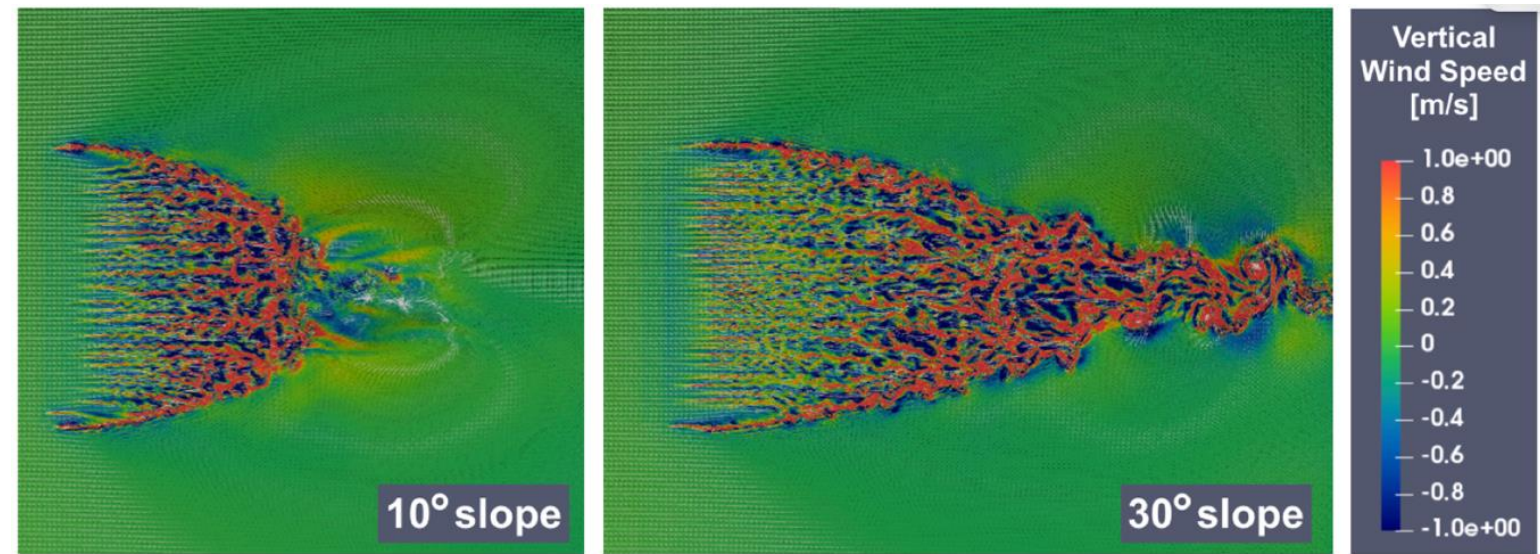

Figure 1 - Results from FIRETEC simulations of grass fires on slopes with the upstream wind aligned parallel to the slope. Colors indicate the wind velocity component that is perpendicular to the land surface.

\section{Conclusions}

Models such as FIRETEC are in continual need of validation and are not replacements for observations. However, this investigation adds perspective to the investigation of topography influences on fire behavior. Observations and experiments can subsequently be designed to test modeling-based hypotheses, supporting or refuting model results, and thus provide critical information to continually assess the validity of models and keep their applicability in perspective (Canfield et al. 2014).

\section{References}

Canfield JM, Linn RR, Sauer JA, Finney M, Forthofer J (2014) A numerical investigation of the interplay between fireline length, geometry, and rate of spread. Agricultural and Forest Meteorology 189-190, 48-59.

Linn RR, Winterkamp JL, Weise DR, Edminster C (2010) A numerical study of slope and fuel structure effects on coupled wildfire behaviour. International Journal of Wildland Fire 21 (4), 396417.

Liu N, Wu J, Chen H, Zhang L, Deng Z, Satoh K, Viegas D, Raposo J (2014) Upslope spread of a linear flame front over a pine needle fuel bed: The role of convection cooling. Proceedings of the Combustion Institute. 35. 10.1016/j.proci.2014.05.100.

Pimont F, Dupuy JL, Linn RR (2012) Coupled slope and wind effects on fire spread with influences of fire size: a numerical study using FIRETEC. International Journal of Wildland Fire 21 (7), 828842.

Raposo J, Cabiddu S, Viegas D, Salis M, Sharples J (2015) Experimental analysis of fire spread across a two-dimensional ridge under wind conditions. International Journal of Wildland Fire. 24. 10.1071/WF14150.

Rossa C, Davim D, Viegas D (2015) Behaviour of slope and wind backing fires. International Journal of Wildland Fire. 24. 10.1071/WF14215.

Silvani X, Morandini F, Dupuy JL (2012) Effects of slope on fire spread observed through video images and multiple-point thermal measurements. Experimental Thermal and Fluid Science. 41. 99111. 10.1016/j.expthermflusci.2012.03.021.

Viegas D, Raposo J, Figueiredo A (2013) Preliminary Analysis of Slope and Fuel Bed Effect on Jump Behavior in Forest Fires. Procedia Engineering. 62. 1032-1039. 10.1016/j.proeng.2013.08.158. 